\title{
Online Food Retailing: Is Market Segmentation The Key To Success?
}

Timothy P. Shea, (E-mail: tshea@umassd.edu), University of Massachusetts, Dartmouth Louis J. Zivic, (E-mail: lzivic@fsc.edu), Fitchburg State College

\begin{abstract}
The online grocery business was one of many e-commerce opportunities from the late 1990s that was full of promise and resulted in disappointment. Based on a review of current literature and telephone surveys with managers from a number of the top 10 retail grocers in the United States, the importance of market segmentation emerges. Technology is less of an issue than several years ago. The reality of the online grocery business as a niche market has sunk in. Enormous data warehouses with customer data are now ready to be analyzed. Market segmentation is now both possible and critical for the near future to identify how to define and implement a profitable online grocery presence.
\end{abstract}

\subsection{Introduction}

T

his is the fourth paper in a series that has followed the evolution of the online grocery business in the United States over the past several years (Zivic and Shea 2002, Shea and Zivic 2001, Zivic and Shea 2000). Just 3 years ago, after surveying the New England retail food industry, "pure play" online startups, such as Peapod, Streamline, WebVan, and Shoplink, were ongoing, mostly unprofitable but full of promise, while the traditional retail chains had mostly adopted a "wait-and-see" attitude. One year later the survey was replicated. The "pure plays" were still unprofitable and, while the traditional retail chains were still moving cautiously in the $\mathrm{B} 2 \mathrm{C}$ arena, they were much more active in developing their B2B capability where cost benefits were more predictable. Lack of profits in the online grocery segment in the United States was still holding back large-scale acceptance. Last year, based on phone interviews with several key figures in the national retail food industry, the meltdown of the "pure play" online grocers (along with the rest of the dot.com sector) seemed to keep the US retail grocers skittish about the online grocery business. Meanwhile, two large international grocers, Ahold and Tesco, became the leaders in moving forward with the online grocery business in the US.

In summary, in spite of great promise and fanfare, a predicted market of over $\$ 10$ billion in the United States, and large investments, the online grocery business did not boom as expected over the past few years. The business model used was typically one of building scale and offering the customer the same prices online as in the store as well as nominal, if any, delivery charges (Anonymous1, 2002). When all was said and done, this model simply proved to be financially unsustainable.

Today, Ahold USA -- the fourth largest retail grocery company in the United States and subsidiary to the second largest retail grocer in the world, Dutch Ahold, is one of a few top 10 retail grocery chains pushing forward with the online grocery business (Top 10 based on Triversity, 2001). Ahold's online grocery business in the United States even expects to be profitable by 2003. They believe a new model was the answer to profitability. Bob Tobin, Chairman of Ahold USA, states "The new model will force people to realize that when you get a service, just like everything else in life, you have to pay for it" (Anonymous1, 2002).

Implied in Bob Tobin's assessment is that the retailer needs to find the right subset of customers who will embrace a model for online grocery shopping that includes greater cost. Naysayers assert that the razor thin margins

Readers with comments or questions are encouraged to contact the authors via email. 
in the retail food industry make the online grocery business unrealistic. People expect savings not greater costs when shopping online. And Juniper Media Matrix Senior Researcher Ken Cassar found that the grocery store experience for customers was not nearly as bad as first thought. However, Forrester Research found that the number of online grocery shoppers increased from 3.7 to 5.0 million between 1999 and 2001 (Totty and Grimes, 2002) and the percent of online grocery shoppers who use the online option regularly has increased from $14 \%$ to $43 \%$ between 2000 and 2002 (Morganosky and Cude, 2001).

So, who are the online grocery shoppers? Today, loyalty cards that customers hand the cashier and software that tracks each person's movement on the company web site are just two ways that grocery stores are gathering unprecedented amounts of customer data. Data warehouses along with data mining and OLAP (On-line analytic processing) analysis tools offer new and more comprehensive means for analyzing the data. The potential for effective customer segmentation has never been greater. This paper will explore the current thinking about business-toconsumer e-commerce (B2C) and, based on interviews with key personnel in a majority of the top ten grocery store chains in the United States, whether customer segmentation is becoming a driving force in being a successful player in the $\mathrm{B} 2 \mathrm{C} \mathrm{e}$-commerce arena in the online grocery business.

\subsection{What Is Happening To B2C E-Commerce}

Online retailing (B2C) was supposed to be flourishing by the year 2002. Yet today, it only accounts for 1 percent of retail sales (Yen, 2001). However, much has been learned during the ups and downs of the dot.com world over the past few years. For example, back office systems -- business-to-business (B2B) systems that connect pieces of the value chain together - needed to be developed to support B2C, to the tune of tens of billions of dollars.

Also, B2C has been found to be far more than just about the final sale. Businesses have learned that company web sites provide a whole new way of communicating with their customers and providing information, in good times and bad. Normal, day-to-day communications online might include pre-sale information such as product specifications and reviews, special coupons, tips, and products only available through the Internet. In bad times, for example Ford's recent problem with Firestone tires, public perception was largely established by the information available on the Internet (Totty, 2001). However, the basic desires of the consumer, whether in the brick-and-mortar store or on the Internet seems the same. People do not want relationships with companies; they want good products and services at competitive prices, convenience, and the confidence that is typically conveyed through dependable brands (Earl, et. al., 2001).

Consumer behavior has also impacted the growth of B2C e-commerce as $\mathrm{B} 2 \mathrm{C}$ requires changing consumer transaction habits (Totty, 2001). And, simply, "customers will change their behavior when the benefit outweighs the cost" (Earl, et. al., 2001). Faith Popcorn, a long time guru in consumer trends, has stated that a new consumer trend requires at least 10 years to become mainstream. Commonplace use of ATMs took that long. B2C, at most, is only 5 years old. And the road is likely to be bumpy. Consumer behavior is still not a science. Consumers may still resist an opportunity in spite of numerous stimuli to adopt (Toddy, 2001).

Today, a number a success stories are in place. J. Crew, an upscale catalog retailer, for the first time has more sales via the Internet than their catalog sales. And they have done this by expanding their number of customers, not just cannibalizing previous phone orders to online orders (Tedeschi, 2002). Other winners in the online marketplace include Ebay, Travelocity, Monster.com, Schwab, and Dell (Totty, 2001). Within the online grocery business, Tesco of the UK is the largest (Earl et. al., 2001). Common characteristics of successful online retailers include a product that: is information intensive (e.g., Monster.com and Schwab); does not need to be tried on, seen or examined in person (e.g. Travelocity); and has a delivery weight that is small compared to cost so delivery does not kill the profit margin (e.g., Dell computers). Hybrid stores that are selling across multiple channels (e.g., stores, catalogs, and online) are fairing better than pure, online stores. Finally, frequency and size of each order is more important than the number of customers. (Pastore 2002, Totty 2001, Yen 2001). 
Earl, et. al. (2001), summarizes how B2C E-commerce is moving into its second generation:

\begin{tabular}{|l|l|}
\hline \multicolumn{1}{|c|}{$\mathbf{1}^{\text {st }}$ Generation e-Commerce } & \multicolumn{1}{c|}{$\mathbf{2}^{\text {nd }}$ Generation e-Commerce } \\
\hline Pure play & Multi-channel \\
\hline Web design & Multi-tier architecture \\
\hline e-CRM & Customer-centered marketing \\
\hline Supply chain management & Demand chain management \\
\hline E-strategy & Business strategy \\
\hline E-commerce & M-commerce \\
\hline
\end{tabular}

Multi-channel e-commerce refers to the need to provide options to the consumer - e.g., in-store, mail order, or online. Each channel requires a channel (and product) strategy as well as integration across channels, especially integration of information systems. A multi-tier IT architecture integrates data from web sites, primary data collection, loyalty cards, and various channel and product transaction processing systems into data warehouses in order to provide unprecedented analysis and understanding of operations and the customer. Customer-centered marketing uses the customer information to refocus existing e-CRM initiatives on more closely meeting customer needs. When applied correctly, through interactive information exchange as one example, areas of loss and profit can be identified almost immediately. Demand chain management will be based on better understanding of the customer demand balanced against detailed supply information. Business strategy instead of E-strategy highlights the integrated, company-wide approach in the second generation of e-commerce. M-commerce, or mobile commerce, is the next significant technology that is offering a whole set of new options to connect with the customer. (Anonymous2 2001, Anonymous4 2002, Earl et. al. 2001)

One example representative of the changing ability to gather and distribute information is the difference in speed in testing marketing concepts. According to Mr. Lafley, President and CEO of Proctor and Gamble: "A year or two ago, we would test thousands of concepts round the world with consumer panels. These tests would take 6-8 weeks to complete and were expensive. Today, we test the majority of our concepts via the Internet within 48 to 72 hours at a fraction of the cost and with equal or higher reliability." (Weich, 2002, p. 59).

Our premise is that customer segmentation is an important part of each of the second-generation ecommerce components Earl describes, both for identifying which new customers to focus upon and how to best retain existing customers. The information available today, in quantity and timeliness, provide for far deeper analysis, for example, "how various segments respond to different types of advertising or whether a particular customer is likely to seek out a competitors products" (Anonymous5, p.51). The following sections explore what market segmentation is and how big a role it is playing in today's online grocery business.

\subsection{Market Segmentation}

According to Arens (2002), market segmentation as a concept came to the fore during the 1960s and 1970s. Market segmentation, in a conventional sense, means developing products and marketing mixes to meet the needs and wants of particular market segments or niches. Over time, major market segments become saturated and product life cycles grow shorter. Sophisticated marketers develop new methods such as positioning, niche marketing, micromarketing, and now with the advent of the Internet, even one-to-one marketing which has tremendous potential beyond present day direct mail techniques. Today's segments are even getting smaller and modern technology helps satisfy the needs for smaller segments while making a profit.

Shared customer characteristics as a concept is critical to market segmentation. Consumers of products leave footprints in the sand - the visible signs of where they live and work, what they buy, and how they spend their time. Product companies and retailers alike can then identify consumers with similar needs and wants. The outcome then becomes finding that segment or opportunity where a product or service fits. Today, manufacturers and retailers have to be aware of rapidly changing consumer demographics that are impacted by a domestic mobile society that is increasingly proficient in the use of modern technology and eager to utilize it. 
As discussed in the previous section, massive amounts of consumer and product data are being collected and are becoming available through integrated databases, data warehouses and more sophisticated reporting and analytic tools. As such, the capability for market segmentation is unprecedented. For example, a "web-based shopping experience can be completely individualized in a way that is impossible in a conventional store, creating new opportunities" (Anonymous2, p.3). The next section discusses the role of market segmentation in the online grocery business.

\subsection{Market Segmentation And The Successful Online Grocery Business}

From Earl's common characteristics of the successful online retailer detailed previously, one can see that the retail grocery business is not a perfect fit. Personal inspection before buying is often important for the retail grocery store customer and delivery cost versus weight is high, especially for small orders. With these challenges, the need for market segmentation becomes even more important. Are there emerging segments of Internet users who would like the convenience of the Internet in ordering groceries?

\subsection{Previous Studies}

One market segmentation study on online grocery buyers indicated that customers are upscale (income over $\$ 70,000$ ), young (under 45), and educated (some college) where saving time is the key benefit (Morganosky and Cude, 2001). Another study reported a similar profile for American online grocery shoppers: 35 to 44 year old, white female homeowner, household income of 50 to 80 thousand dollars per year, with teenage children (Anonymous3). In addition, the per order profit is not important if they shop regularly, for example, once a week. According to Darrel Rigby, Director of Bain \& Co., "Online retailers should take a more focused approach because all customers are not created equally. It is more important to have a loyal group of the right customers than to have lots of the wrong customers" (Pastore, 2002).

Ahold, one of the few large retail grocers actively in the online grocery business with prospects for online profits in the near future, has narrowed and focused its online presence to a smaller number of cities, a scaled down list of commonly wanted products, a minimum order of fifty dollars, and a delivery charge. Even with an average order of $\$ 132$, they can only clear a small profit, suggesting segmentation is essential. Safeway Inc. is using the online grocery model that Tesco developed in the UK. They successfully use store level inventory, special grocery carts with the order and a map of the store displayed on a screen, and use pickers during off-peak time in order to avoid interfering with the regular in-store customers (Toby and Grimes, 2002). Other retail grocers are viewing the online grocery business as a growth area but only in niche markets. Products like fine wines and luxury, gourmet, and organic foods are all attractive online markets since the products yield higher profit margins and typically attract knowledgeable customers (Anonymous4, 2002).

\subsection{Results From A New Telephone Survey}

A confidential telephone survey of key personnel from half the top ten retail grocery chains in the United States, representing over $\$ 100$ billion in sales, provided up-to-date information on the status and future on the online grocery business and the importance of market segmentation. All the participants were managers in corporate headquarters except one who is in the marketing area and one who is in the IT area.

Overall, the typical market segment for online grocery buyers was similar to the studies mentioned above but with a specific emphasis on life stage - younger families with small children, good family income (approximately $\$ 70,000$ ) who are time starved. Comfort with the computer is a must since profitability depends on the shopper using the online option regularly.

Interestingly, home delivery, in spite of the expense is alive and well. The "pick and deliver" model seems to be the prevailing approach. This approach requires fairly dense population areas and a minimum order size to be profitable. Back office systems, including those that support B2B systems, still need to improve to facilitate B2C ecommerce. In general, the US retail grocery business is still a late adopter in the $\mathrm{B} 2 \mathrm{C}$ world. European cities are 
ahead, partly due to population density, parking problems in the large cities, and cultural factors such as the habit of shopping every day. Tesco of the UK, the largest online grocer in Europe, has been profitable for several years in England and is considered five years ahead of the US in the online grocery business.

Several organizations mentioned they use web sites, loyalty cards, and surveying to collect consumer data. Data is stored in a data warehouse on as many as 50 million customers and analyzed using data mining tools. Competitive objectives include getting business from competitors through the use of online grocery shopping.

Overall, the future of B2C in the grocery business in the United States is considered good, in the near term, especially as back office systems are brought up to date. The largest growth is anticipated for upscale and niche customers. By definition, defining the right niche is market segmentation. As such, for the near term, market segmentation will remain an essential part of defining and implementing a profitable online channel for retail grocery chains.

\subsection{Conclusion}

Market segmentation, as it feeds all components of e-commerce, is growing more important both as the ability to collect and analyze customer-related data has improved exponentially and the competitive climate -- especially with the economy in a downturn -- demands better and better understanding of the customer for assessing strategic opportunities and creating competitive advantages. The online grocery business, generally proven to be a difficult business to run profitably, is in special need for market segmentation given the business' inherent characteristics such as delivery costs and the need for many customers to physically view the products before buying. Based on current literature and a telephone interview of managers in the large retail grocery chains suggests that upscale, time-starved, young families living in or near cities who agree to a minimum purchase are the market segment that is currently needed to make online grocery shopping profitable.

The future for online grocery shopping, while less optimistic than a few years ago, is still promising. For the long term, the computer-savvy twenty-something consumers today need to move into the targeted life stage of young families with moderate to upscale household incomes. The back office systems that support both B2B and B2C must continue to improve and integrate information, especially information across channels such as the online, brick-and-mortar, and catalog businesses.

The opportunity and need for market segmentation will continue as technology relentlessly moves forward. In-store Kiosks in grocery stores today provide information (e.g., coupons and specials), commerce (e.g., putting in a deli order or self-check out), and another opportunity to learn more about the customer and sell the customer (e.g., cross-selling and up-selling). Upcoming technology is likely to include hand-held wireless units that scan items as the shopper is shopping (Greengard, 2002). Third party validators on the Internet will be important for consumers to trust buying from an unknown company, for example, with a small, international, niche grocery store (Totty, 2001). $3 \mathrm{D}$ visuals and the ability to actually sample aromas will be coming to the Internet. And finally, m-commerce (mobile commerce) is beginning to define a whole new arena. "The new mobile technologies are to the e-business world as the PC was to the computer world twenty years ago" (Earl et. al. 2001, p. 10). Proper attention to market segmentation, we believe, will largely dictate whether the retail grocery stores - with their thin profit margins -- will apply these and other technologies effectively and profitably.

Research support provided by Ian J. Murray, Fitchburg State College.

\section{References}

1. $\quad$ Anonymous1. "B-Travel: Going Dutch on the Groceries”, Delta Sky, May 2002.

2. Anonymous2. "B2X Online Relationship Management for and Extended Enterprise", atgDynamo White Paper. October 2001.

3. Anonymous3. "Online Groceries Set for Growth Explosion", AgriFood Innovations News Release. October 11, 2001, retrieved from www.agrifood.com/news 4/18/2002.

4. Anonymous4. "M-Commerce Road map for Grocery Shopping", Willard Bishop Consulting, www.bishop- 
consulting.com/m_commerce.cfm, retrieved 4/23/02.

5. $\quad$ Anonymous5. "Improving Customer Care", $I Q$, March/April 2002, pp. 50-51.

6. $\quad$ Arens, P. Contemporary Advertising, McGraw-Hill, 2002.

7. Connolly, J. P. “Can CRM Win and Retain Loyal, Repeat Customers?” Infoworld, April 9, 2001.

8. Earl, Michael, Mark Frohlich, Kathy Hammond, Fernando Suarez, and Chris Voss, "Second Generation EBusiness: A Situation Report on the Network Economy", London Business School White Paper, 2001.

9. $\quad$ Greengard, Samuel, "The Evolution of Retail”, IQ, March/April 2002, pp. 43-49.

10. Morganosky, M.A. \& Cude, B.J. "Consumer responses to online food retailing", Journal of Food Distribution Research Family Economics NEWS, CSREES-USDA, December 2001/January 2002.

11. Pastore, Michael, "Pure Plays Face Trouble in E-Commerce Shakeout" Markets Retailing, http://cyberatlas.internet.com/markets/retailing/article/0,1323,6061_397301,00.html, retrieved 4/18/02,

12. Shea and Zivic. "Click and Mortar versus Dot-Com: Who Will Win the Online Grocery Business?", Applied Business Research Conference 2001, Cancun Mexico, March 2001.

13. Tedeschi, Bob. "E-Commerce Report: J. Crew Reaches a Milestone as its Sales Over the Web Exceed Sales From its Catalog", New York Times, Section C, Page 6, March 25, 2002.

14. Totty, Michael and Ann Grimes, "If at First You Don't Succeed ...", Wall Street Journal, February 11, 2002, p. R3.

15. Totty, Michael, “The Researcher”, Wall Street Journal, July 16, 2001, p. R20

16. Triversity Top Supermarkets, 2001, www.stores.org/archives/2001 topsprmrkts.html, retrieved 5/13/02.

17. Weich, Shanon. “Constant Innovation,” March/April 2002, pp. 59. IQ, March/April 2002.

18. Yen, Jody. "Who Says E-Commerce is Dead", article date 12/5/01, retrieved from www.forbes.com 5/9/02.

19. Zivic, Louis and Timothy Shea, "The Impact of Electronic Commerce on the Globalization of the On-Line Grocery Business", International Business \& Economics Research Journal, Vol. 1, No. 1, winter 2002.

20. Zivic, Louis and Timothy Shea. "Electronic Commerce in the Retail Food Industry: Price of Being the Late Adopter". Applied Business Research Conference 2000. Puerta Vallarta, Mexico; March, 2000. 